\title{
ANH THY NGUYEN, L'écriture de l'histoire à la fin du Moyen Âge: une étude textuelle et matérielle des "Mémoires" de Jean de Haynin
}

\section{Maria Colombo Timelli}

\section{(2) OpenEdition}

\section{Journals}

\section{Édition électronique}

URL : http://journals.openedition.org/studifrancesi/14953

DOI : 10.4000/studifrancesi. 14953

ISSN : 2421-5856

Éditeur

Rosenberg \& Sellier

\section{Édition imprimée}

Date de publication : 1 décembre 2018

Pagination : 478

ISSN : 0039-2944

\section{Référence électronique}

Maria Colombo Timelli, « ANH THY NGUYEN, L'écriture de I'histoire à la fin du Moyen Âge: une étude textuelle et matérielle des "Mémoires" de Jean de Haynin », Studi Francesi [En ligne], 186 (LXII | III) | 2018, mis en ligne le 01 janvier 2019, consulté le 06 janvier 2021. URL : http://journals.openedition.org/studifrancesi/ 14953 ; DOI : https://doi.org/10.4000/studifrancesi.14953

Ce document a été généré automatiquement le 6 janvier 2021

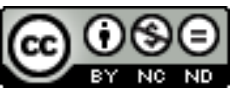

Studi Francesi è distribuita con Licenza Creative Commons Attribuzione - Non commerciale - Non opere derivate 4.0 Internazionale. 


\title{
ANH THY NGUYEN, L'écriture de l'histoire à la fin du Moyen Âge: une étude textuelle et matérielle des "Mémoires" de Jean de Haynin
}

\author{
Maria Colombo Timelli
}

\section{RÉFÉRENCE}

ANH THY NGUYEN, L'écriture de l'histoire à la fin du Moyen Âge: une étude textuelle et matérielle des "Mémoires" de Jean de Haynin, in «Questes. Revue pluridisciplinaire d'études médiévales», 36, 2017, pp. 85-107.

L'œuvre de Jean de Haynin, homme d'armes sous Philippe le Bon et Charles le Téméraire, est peu connue: raison de plus pour signaler cet article paru dans la revue des jeunes chercheurs médiévistes de la Sorbonne (école Doctorale I «Mondes anciens et médiévaux»). Anh Thy Nguyen, de l'Université catholique de Louvain, offre une présentation des Mémoires, qui couvrent les événements militaires et dynastiques bourguignons des années $1465-1477$, sous trois points de vue complémentaires. Il s'agit d'abord de prouver le caractère autographe du manuscrit KBR II 2545 (dont existent deux copies partielles du xvI $I^{\mathrm{e}}$ siècle et une complète $d u \mathrm{XVIII}^{\mathrm{e}}$ ), qui garde les traces de plusieurs étapes de rédaction; on passe ensuite à l'analyse de la présence de Jean de Haynin «auteur» dans son texte, pour conclure sur sa volonté de «fabriquer» le récit historique à partir d'une série de sources: outre les témoignages oraux, des pièces d'archives - les unes et les autres indiquées explicitement par Jean-, et même des documents privés et des pièces littéraires. 